\title{
Letramento imagético e EJA no contexto de atividades remotas durante a pandemia
}

\author{
Image literacy and youth and adult education in the context of remote \\ activities during the pandemia
}

\section{Alfabetización de imagen y eja en el contexto de actividades remotas durante la pandemia}

Daiane Martins Bocasanta ${ }^{1}$; Clevi Elena Rapkiewicz²; Talia Prates da Luz ${ }^{3}$

\section{RESUMO}

Este trabalho objetiva descrever e analisar uma sequência didática elaborada pelos componentes curriculares Cultura Digital e Polivalência e proposta para alunos dos anos iniciais da Educação de Jovens e Adultos (EJA) de uma escola pública federal de Porto Alegre-RS, no contexto de atividades remotas durante a pandemia. De modo específico, visou a promover o letramento imagético dos estudantes através de atividades relacionadas à leitura de imagens, entendimento de passagem temporal através de leitura imagética e criação de narrativas com recursos digitais de fácil acesso para eles. O referencial teórico utilizado situa-se no entrecruzamento de estudos sobre letramentos e EJA. A metodologia utilizada é de cunho qualitativo. O material analisado é composto por anotações em diário de campo e atividades realizadas pelos alunos. Os resultados situam-se em dois eixos: 1) verificou-se a potencialidade da proposição de atividades de letramento imagético para alunos da EJA, apesar dos limites impostos pela pandemia de Covid-19 e do acesso restrito às tecnologias digitais; e 2) observou-se avanços em relação ao processo de letramento dos discentes.

Palavras-chave: Letramento imagético; Sequência didática; Anos iniciais da EJA; Pandemia de Covid-19; Multiletramento.

\begin{abstract}
This paper aims to describe and analyze a didactic sequence elaborated by the curricular components Digital Culture and Polyvalence and a proposal for students in the early years of Youth and Adult Education of a federal public school in Porto Alegre-RS, in the context of remote activities during the pandemic. Specifically, it aimed to promote students' image literacy through activities related to image reading, understanding the passage of time through imagery reading and creating narratives with easy-access digital resources for them. The theoretical framework used is located at the intersection of studies on literacy and Youth and Adult Education. The methodology used is of a qualitative nature. The analyzed material produced is composed of notes from a field diary and activities carried out by the students. The results are located in two axes: 1) the potentiality of proposing imagery literacy activities for Youth and Adult Education students was verified, despite the limits imposed by the Covid-19 pandemic and the restricted access to digital technologies; and 2) advances were observed related to the students' literacy process.
\end{abstract}

Keywords: Image literacy; Following teaching; Early years of Youth and Adults Education; Covid-19 pandemic; Multiliteracy.

${ }^{1}$ Doutora em Educação e Professora do Colégio de Aplicação da Universidade Federal do Rio Grande do Sul (UFRGS), Porto Alegre/RS - Brasil. E-mail: daianebocasanta@gmail.com

${ }^{2}$ Doutora em Engenharia de Sistemas e Computação e Professora do Colégio de Aplicação da Universidade Federal do Rio Grande do Sul (UFRGS), Porto Alegre/RS - Brasil. E-mail: clevi.capufrgs@gmail.com

${ }^{3}$ Graduanda de Licenciatura em Arte Visuais na Universidade Federal do Rio Grande do Sul (UFRGS), Porto Alegre/RS - Brasil. E-mail: taliapratesdaluz@gmail.com 


\section{RESUMEN}

Este trabajo tiene como objetivo describir y analizar una secuencia didáctica elaborada por los componentes curriculares Cultura Digital y Polivalencia y una propuesta para estudiantes en los primeros años de Educación de Jóvenes y Adultos (EJA) de una escuela pública federal en Porto Alegre-RS, en el contexto de actividades remotas durante la pandemia. Específicamente, tuvo como objetivo promover la alfabetización en imágenes de los estudiantes a través de actividades relacionadas con la lectura de imágenes, la comprensión del paso del tiempo a través de la lectura de imágenes y la creación de narrativas con recursos digitales de fácil acceso para ellos. El marco teórico utilizado se ubica en la intersección de los estudios sobre alfabetización y EJA. La metodología utilizada es de carácter cualitativo. El material analizado está compuesto por notas en un diario de campo y actividades realizadas por los estudiantes. Los resultados se ubican en dos ejes: 1) se verificó la potencialidad de proponer actividades de alfabetización en imágenes para los estudiantes de EJA, a pesar de los límites impuestos por la pandemia Covid-19 y el acceso restringido a las tecnologías digitales; 2) se observaron avances en relación al proceso de alfabetización de los estudiantes.

Palabras clave: Alfabetización en imagen; Secuencia didáctica; Primeros años de EJA; Pandemia de COVID19; Multialfabetismo.

\section{INTRODUÇÃO}

Com a proliferação do uso de tecnologias digitais em nossa sociedade, as situações sociais de uso da leitura e da escrita, modificam-se e multiplicam-se a cada dia, o que nos demanda outros conhecimentos. Dentre esses, destacamos aqueles relativos ao uso dessas tecnologias, bem como, uma ampla gama de letramentos que permitem a leitura, a interpretação e a produção de textos construídos a partir de diferentes modalidades da linguagem, como escrita, fala, sons, imagens, gestos, etc. Ao mesmo tempo, a expansão do uso de tecnologias digitais e do acesso a redes sociais e aplicativos de troca de mensagens, com a consequente disseminação das fake news expõe a necessidade da ampliação do trabalho com práticas de letramentos na escola. Favero e Cardoso (2020), aludindo a dados de uma pesquisa realizada pela BBC em 2019, mostram que as pessoas pertencentes às classes $C, D$ e E, isto é, as menos favorecidas economicamente no Brasil, são as mais suscetíveis a espalhar fake news. De acordo com as autoras (FAVERO e CARDOSO, 2020, p. 3) "isto pode ser devido a tendência que estas classes têm de utilizar planos de internet móvel restritos que disponibilizam acesso livre ao WhatsApp, mesmo quando o acesso liberado pelo plano se esgota". Essas condições de acesso, somadas às lacunas apresentadas por esses sujeitos no processo de letramento, por vezes faz com que esses usuários acabem lendo somente as manchetes que recebem e não o conteúdo ou fonte da notícia.

Dado o exposto, podemos afirmar que boa parte dos alunos que retomam seus percursos de escolarização na Educação de Jovens e Adultos (EJA), pertence às classes menos favorecidas economicamente, com acesso limitado ao ambiente digital e bastante suscetível a informar-se e disseminar informações através de grupos de WhatsApp e de outros aplicativos de compartilhamento de mensagens. Apesar de não tratarmos neste trabalho das fake news, optamos por expor essa problemática aqui, pois ela confere ainda mais sentido à introdução e desenvolvimento de práticas específicas relacionadas à diferentes letramentos. Corrobora com essa argumentação a seguinte passagem da BNCC (BRASIL, 2017, p, 69):

Eis, então, a demanda que se coloca para a escola: contemplar de forma crítica essas novas práticas de linguagem e produções, não só na perspectiva de atender às muitas demandas sociais que convergem para um uso qualificado e ético das TDIC necessário para o mundo do trabalho, para estudar, para a vida cotidiana etc. - , mas de também fomentar o debate e outras demandas sociais que cercam essas práticas 
e usos. É preciso saber reconhecer os discursos de ódio, refletir sobre os limites entre liberdade de expressão e ataque a direitos, aprender a debater ideias, considerando posições e argumentos contrários. Não se trata de deixar de privilegiar o escrito/impresso nem de deixar de considerar gêneros e práticas consagrados pela escola, tais como notícia, reportagem, entrevista, artigo de opinião, charge, tirinha, crônica, conto, verbete de enciclopédia, artigo de divulgação científica etc., próprios do letramento da letra e do impresso, mas de contemplar também os novos letramentos, essencialmente digitais. [grifos nossos]

Dentre esses "novos letramentos", de que trata a BNCC, aqui, em específico, abordaremos o trabalho com letramento imagético voltado para estudantes dos anos iniciais da EJA, conforme explicitamos mais adiante. Para tanto, faremos uso de alguns estudos acerca de letramentos, tais como os de Soares (2002, 2014), Kalantzis et al. (2020), Rodrigues (2014), Ribeiro e Coscarelli (2014), Fonseca e Simões (2014), Terra (2013), Dondis (2007) e Rojo (2006). Cabe aqui destacar que nosso entendimento acerca dos letramentos acompanha Soares (2002), para quem letramento vai além das práticas de leitura e escrita, ou ainda, os eventos que se relacionam com o uso e função dessas práticas. A autora também não define letramento em termos do impacto ou das consequências da escrita sobre a sociedade. Em seu entendimento, Soares (2002, p. 145) percebe letramento como sendo o "[...] estado ou condição de quem exerce as práticas sociais de leitura e de escrita, de quem participa de eventos em que a escrita é parte integrante da interação entre pessoas e do processo de interpretação dessa interação [...]" [grifos da autora].

Em 2020 iniciamos mais uma crise que não esperávamos no contexto educativo, precipitada pelo contexto imposto pela pandemia de Covid-19. O isolamento social e a consequente suspensão das atividades escolares fizeram emergir questões urgentes que transitam em torno da finalidade da educação na contemporaneidade (ZORDAN; ALMEIDA, 2020). Na impossibilidade de assumirmos um tempo sabático ou não produtivo em termos de escolarização, afinal, vivemos em uma sociedade que nos impulsiona a não parar, mesmo frente a cenários apocalípticos, escolas, professores e estudantes precisaram (re)inventar modos de (re)existir enquanto categorias fixas. Com isso, não queremos dizer que sugerimos que a escola permaneça apática e isolada durante a pandemia, mas acompanhamos Zordan e Almeida (2020, p. 13) visando a constituir outro sentido ao apelo para não "pararmos": "pensamos em uma educação no presente e para o presente no convívio educacional, mesmo em isolamento, como formação; não uma educação para uma vida futura, mas na própria vida-vivente".

Dando seguimento a essa argumentação, as autoras reivindicam "paragens em devir", como momentos que possibilitem um repouso necessário ao processo de criação. Nessas pausas estaria previsto identificar "nas experiências cotidianas miúdas, nas fissuras e nas brechas da convivência, em que a louça, os panos e as tarefas estão contidas, processos formativos" (ZORDAN; ALMEIDA, 2020, p. 13). Afinal, não podemos simplesmente invisibilizar as marcas deixadas pela invasão das casas pelas escolas e vice-versa, nos processos de escolarização vivenciados no contexto não presencial.

Por outro lado, como nos mostram estudos como o de Fantinato et al. (2020), as medidas de distanciamento social para evitar o contágio pela Covid-19, precipitadas pela pandemia a partir de março de 2020 e o consequente deslocamento das salas de aula para o contexto virtual tiveram efeitos nefastos na Educação no Brasil e, em especial, na modalidade EJA. Nessa direção, destacamos também, que a "domiciliação" do escolar, transladado para o âmbito doméstico expôs e aprofundou as desigualdades de conexão existentes em diferentes países do mundo, bem como, evidenciou as limitações de plataformas digitais que permitem menos do que prometiam e até mesmo 
dificultam algumas ações básicas que constituem a escola, da forma que ela nos é familiar (DUSSÉL, 2020).

No contexto escolar aqui analisado, isso pode ser traduzido a partir da precariedade de acesso a equipamentos, a conexão de internet e principalmente a falta de habilidade de estudantes adultos e idosos em processo de alfabetização, para manejar os meios que permitem, ainda que de forma limitada, - no interior da realidade projetada pela pandemia - a realização de um processo que nos remete à escolarização como a concebemos primeiramente. Ao recebermos a notícia de que a escola onde atuamos junto à turma de anos iniciais da EJA iria, assim como as demais, fechar, e, que teríamos que iniciar um novo modo de manter o vínculo com nossos estudantes, através dos Estudos Dirigidos Remotosii, começamos a pensar em como enfrentar esse desafio.

Observávamos no contexto presencial e em pesquisas realizadas previamente (BOCASANTA, WANDERER e KNIJNIK, 2016; 2019) que os alunos enunciavam dificuldades em lidar com tecnologias digitais, bem como, o desejo de aprender mais sobre elas, o que já nos mobilizava no sentido de empreender práticas pedagógicas de letramento digital (BOCASANTA e RAPKIEWICZ, 2019). Do mesmo modo, algumas pesquisas têm indicado potencialidades advindas da oferta de práticas de letramento digital para pessoas idosas em processo de escolarização na EJA (SILVA e JUNIOR, 2020) ou ainda, em cursos de inclusão digital para a terceira idade no contexto pandêmico (DEODORO et al, 2020).

Cabe destacar também, o que dizem os documentos mais recentes que organizam a EJA no Brasil. $\mathrm{A}$ Resolução no 01/2021, de 25 de maio de 2021 (BRASIL, 2021, p. 1), que "institui Diretrizes Operacionais para a Educação de Jovens e Adultos nos aspectos relativos ao seu alinhamento à Política Nacional de Alfabetização (PNA) e à Base Nacional Comum Curricular (BNCC), e Educação de Jovens e Adultos à Distância", prevê que o objetivo dos anos iniciais do Ensino Fundamental na EJA estaria atrelado à alfabetização inicial, bem como a uma qualificação profissional inicial. Tal resolução estabelece, portanto, carga horária obrigatória apenas para o desenvolvimento dos componentes essenciais de alfabetização e das noções básicas de matemáticaiii. Entretanto, mais adiante, esse mesmo documento define no artigo 13:

Os currículos dos cursos da EJA, independente de segmento e forma de oferta, deverão garantir, na sua parte relativa à formação geral básica, os direitos e objetivos de aprendizagem, expressos em competências e habilidades nos termos da Política Nacional de Alfabetização (PNA) e da BNCC, tendo como ênfase o desenvolvimento dos componentes essenciais para o ensino da leitura e da escrita, assim como das competências gerais e as competências/habilidades relacionadas à Língua Portuguesa, Matemática e Inclusão Digital. (BRASIL, 2021, p. 6) [grifos nossos]

Sendo assim, isso apenas reforça a necessidade de investirmos no desenvolvimento de atividades que visem a inserção dos sujeitos dos anos iniciais da EJA na cultura digital, mesmo que de forma remota. Desse modo, o objetivo deste trabalhoiv foi descrever e analisar uma sequência didática elaborada no contexto dos componentes curriculares Cultura Digital e Polivalênciav, realizada com a turma de anos iniciais da EJA de uma escola pública federal de Porto Alegre-RS durante o período de suspensão das aulas presenciais, imposto pelas medidas de prevenção de contágio do novo coronavírus (SARS-CoV-2). Dentre os objetivos específicos dessas atividades, destacamos nessa escrita, a apropriação de práticas de letramento imagético, tal como exploramos mais adiante. 


\title{
2. REFERENCIAL TEÓRICO
}

De forma geral, o termo letramento, refere-se - mas não somente, como veremos a seguir - a estudos sobre escrita e leitura, seus usos, funções e efeitos, tanto em relação aos indivíduos quanto para a sociedade (TERRA, 2013). As discussões acerca dessa temática são múltiplas, heterogêneas e suscitam vigoroso debate entre estudiosos associados a diferentes vertentes. Desse modo, apresentaremos aqui, de forma resumida, algumas das reflexões que ampararam nossas práticas pedagógicas.

Na obra Letramento: um tema em três gêneros, Magda Soares (2014) afirma que a palavra letramento teria sido inserida no vocabulário de especialistas das áreas da Educação e das Ciências Linguísticas na segunda metade dos anos 80 do século passado. A autora, então, recupera o sentido etimológico da palavra, dizendo que ela provém do termo da língua inglesa literacy.

\begin{abstract}
Etimologicamente, a palavra literacy vem do latim litera (letra), com o sufixo - cy, que denota qualidade, condição, estado, fato de ser (como, por exemplo, em innocency, a qualidade ou condição de ser inocente. No Webster's Dictionary, literacy tem a acepção de "the condition of being literate", a condição de ser literate, e literate é definido como "educated; especially able to read and write", educado, especialmente, capaz de ler e escrever. Ou seja: literacy é o estado ou condição que assume aquele que aprende a ler e escrever. Implícita nesse conceito está a ideia de que a escrita traz consequências sociais, culturais, políticas, econômicas, cognitivas, linguísticas, quer para o grupo social em que seja introduzida, quer para o indivíduo que aprenda a usá-la. (SOARES, 2014, p. 17-18) [grifos da autora]
\end{abstract}

Isto é, ao agregar a palavra letramento ao processo de alfabetização, Soares (2014), amplia o significado desse processo incluindo no mesmo a capacidade de fazer usos sociais adequados da leitura e da escrita. Para Soares (2014), o surgimento do conceito de letramento responde a mudanças na sociedade. Uma inferência importante da teorização desenvolvida por Soares (2014) que destacamos aqui é que, mesmo indivíduos considerados analfabetos, ou seja, que não sabem ler e escrever, podem ser em alguma medida, letrados. Um adulto considerado analfabeto, marginalizado social e economicamente, caso viva em um ambiente onde a escrita e a leitura se fazem fortemente presente, "[...] se se interessa em ouvir a leitura de jornais feita por um alfabetizado, se recebe cartas que outros leem para ele, se dita cartas para que um alfabetizado as escreva [...] se pede a alguém que the leia avisos ou indicações afixados em algum lugar, esse analfabeto é, de certa forma, letrado [...]" (SOARES, 2014, p. 24) [grifos da autora]. Contemporaneamente, podemos ainda acrescentar: se esse sujeito faz uso de aplicativos de mensagens em smartphones para enviar recados por áudio ou por escrita através de ditado, se consegue pesquisar acerca de uma receita ou outro tema de seu interesse via comando de voz, se produz e/ou envia imagens e vídeos para outrem, se utiliza memes, emoticons e gifs para se comunicar, entre outros, podemos dizer que ele é em certa medida, letrado, tendo em vista que "faz uso da escrita, envolve-se em práticas sociais de leitura e escrita" (SOARES, 2014, p. 24).

Terra (2013), no entanto, nos alerta que reconhecer a variedade de práticas de letramento em nossa sociedade deve levar em conta que não devemos criar rótulos acerca do que seja ser ou não ser letrado, tendo em vista que existiriam diferentes conceitos de letramento, adaptados a contextos e situações específicas. Desse modo, para alguns "ser letrado pode significar, por exemplo, ter a capacidade de trabalhar em um escritório; para outros, no entanto, significa ser capaz de escrever 
uma carta para amigos/familiares; já para outros, ser letrado é ser capaz de assinar o próprio nome, e assim por diante" (TERRA, 2013, p. 32).

Nos dias atuais, podemos dizer que além de altamente letradas - grafocêntricas -, as sociedades passaram a ser altamente tecnocientificizadas ou no dizer de Lazzarato (2014), maquinocêntricas. Rojo (2006) demarca que com o advento das novas mídias e tecnologias, os gêneros transmutaramse em entidades multimodais. Isso significa que elas "utilizam-se de diversas modalidades de linguagem - fala, escrita, imagens (estáticas e em movimento), grafismos, gestos e movimentos corporais - de maneira integrada e em diálogo entre si, para compor os textos" (ROJO, 2006, p. 45). Nesse sentido, podemos elencar uma série de ações cotidianas em que diversos tipos de letramentos nos são demandados, tais como sacar dinheiro ou imprimir um extrato de uma conta bancária em um caixa eletrônico, conferir o saldo de uma conta através de aplicativo ou via telefone, preencher um cadastro em ambiente virtual para se candidatar a uma vaga de emprego, enviar um e-mail, utilizar aplicativos de mensagem em smartphones, solicitar cadastro em programas sociais do governo, etc.

A ideia de "multiletramentos" teria surgido por volta de 1996, de acordo com Kalantzis et al. (2020), a partir das discussões engendradas no grupo formado pelos autores com colegas de diversas universidades, denominado The New London Group (NLG). Tal conceituação seria resultado de discussões acerca das grandes mudanças motivadas pelas formas através das quais as pessoas estariam construindo e participando de significados. Nesse sentido, o interesse compartilhado pelos participantes do grupo, centrava-se na discussão acerca de uma pedagogia que levasse em conta os multiletramentos. Com isso, buscava-se dar visibilidade a necessidade de se complementar as abordagens convencionais de leitura e escrita com as novidades advindas dos modos como as pessoas constroem significados em ambientes de comunicação contemporâneos. Disso resulta 0 deslocamento do campo do "/etramento (no singular) para letramentos (no plural). Tal deslocamento abarcaria "múltiplas formas de comunicação e construção de sentidos, incluindo os modos visual, auditivo, espacial, comportamental e gestual" (KALANTZIS et al., 2020, p. 19).

Isso porque, para os autores, a escrita deixou de ser a principal forma de construir significados. $\mathrm{Na}$ atualidade, os modos grafocêntricos de produzir significados "podem ser complementados ou substituídos por outras formas de cruzar o tempo e a distância, como gravações e transmissões orais, visuais, auditivas, gestuais e outros padrões de significado" (KALANTZIS et al., 2020, p. 20). Isso nos leva a conclusão de que "uma pedagogia voltada ao ensino de leitura e escrita precisa ir além da comunicação alfabética, incorporando assim, a essas habilidades tradicionais as comunicações multimodais, particularmente aquelas típicas das novas mídias digitais" (KALANTZIS et al., 2020, p. 20). Isso não significa depreciação ou abandono da matemática, da leitura ou da escrita em suas formas tradicionais, afinal, tais conhecimentos são hoje tão ou mais importantes quanto eram antes (KALANTZIS et al., 2020). Dito de outro modo, o que se preconiza é o trabalho de diferentes capacidades em processos de letramento que abarquem tanto o conhecimento de convenções formais de diversos modos, quanto uma comunicação eficiente que leve em conta diferentes ambientes e usos de ferramentas de design de textos que são multimodais. "Diante da tela, o usuário/leitor precisa compreender a função dos links, identificar ícones e signos próprios do gênero (como curtir e 
comentar no Facebook, selecionar emoticons no WhatsApp, inserir imagens, enviar fotos, publicar comentários" (ZACHARIAS, 2016, p.21).

Nesse sentido, temos buscado realizar no âmbito dos anos iniciais da EJA, diversas práticas que envolvam o desenvolvimento do letramento digital. Ribeiro e Coscarelli (2014) definem que "letramento digital diz respeito às práticas sociais de leitura e produção de textos em ambientes digitais, isto é, ao uso de textos em ambientes propiciados pelo computador ou por dispositivos móveis, tais como celulares e tablets, em plataformas como e-mails, redes sociais na web, entre outras". Nesse sentido, as pessoas digitalmente letradas seriam capazes de se comunicar em diferentes situações, respondendo a diversas situações, tanto pessoais quanto profissionais. Destarte, "a busca de informações na internet também implica saber encontrar textos e compreendê-los, o que pressupõe selecionar as informações pertinentes e avaliar sua credibilidade" (RIBEIRO e COSCARELLI, 2014). As autoras ainda demarcam, assim como Kalantzis et al. (2020), que nesses ambientes digitais precisamos levar em conta a multimodalidade. Afinal, nos ambientes digitais, as informações não são apresentadas apenas através de elementos linguísticos tais como palavras e frases. Vídeos, animações, sons, cores e ícones também se fazem presentes. Portanto, "saber ler e produzir textos explorando essas linguagens faz parte das competências dos digitalmente letrados, com exigências sociais e motivações pessoais cada vez mais precoces" (RIBEIRO e COSCARELLI, 2014).

Dado o exposto, acreditamos nos benefícios para alunos de EJA, de um trabalho comprometido com uma pedagogia que leve em conta a questão dos multiletramentos. Dentre esses letramentos, exploramos aqui, de forma mais enfática, o letramento imagético, tendo em vista que, todos os dias somos interpelados por imagens em diferentes formatos e mídias, mas poucos de nós temos habilidades suficientes para contextualizar ou analisar de forma crítica essas imagens.

Rodrigues (2014), ao explicar em que consistiria o letramento imagético utiliza como exemplo as aulas de artes. Segundo o autor, quando trabalha em suas aulas "[...] cores, formas, volumes, equilíbrio, linhas, movimento, espaço, valor, contrastes, texturas, ou seja, com elementos táteis e visuais [...]" ele estaria no nível da alfabetização visual, afinal, sua preocupação nesta etapa estaria alojada na "[...] aquisição de códigos para a análise de uma obra de arte ou de uma imagem" (RODRIGUES, 2014, p. 94). No entanto, quando suas aulas abordam de forma crítica uma obra de arte, buscando verificar "[...] um caráter comunicativo e analisar sua mensagem de maneira filosófica [...]" (RODRIGUES, 2014, p. 94) o professor estaria focando no nível do letramento. Nessa mesma direção, Dondis (2007, p. 4) conjectura que o modo visual forma "todo um corpo de dados que, como a linguagem, podem ser usados para compor e compreender mensagens em diversos níveis de utilidade, desde o puramente funcional até os mais elevados domínios da expressão artística". Apesar de adotar o termo alfabetismo visual e não letramento imagético, Dondis (2007) evidencia que o surgimento de tecnologias de produção e veiculação de imagens trouxe uma nova forma de ver a comunicação e com isso, a educação. Isso provocaria, segundo o autor, a "necessidade urgente de se buscar e desenvolver um sistema estrutural e uma metodologia para o ensino e aprendizado de como interpretar visualmente as ideias" (DONDIS, 2007, p. 14). Apoiando-se em Foucault, Rodrigues (2014, p. 94) argumenta que "[...] o discurso, seja ele literário ou imagético, demonstra a força de poderes de quem o cria, sendo um instrumento de batalhas ideológicas e significativas, daí a importância em compreendê-lo e decifrá-lo por meio do letramento dos estudantes". Nessa direção, enfatiza o autor, o letramento imagético forneceria meios para os sujeitos escolares enfrentarem batalhas conceituais que se lhes apresentam. 


\section{CAMINHOS EMPÍRICOS}

A estrutura metodológica aqui utilizada baseia-se numa abordagem qualitativa de inspiração póscrítica. Como demarca Meyer e Paraíso (2012, p. 16), a vertente de pesquisa pós-crítica entende que a metodologia compõe um jeito específico de perguntar e "[...] de formular questões e de construir problemas de pesquisa que é articulado a um conjunto de procedimentos de coleta de informações que, em congruência com a própria teorização, preferimos chamar de "produção" de informação - de estratégias de descrição e análise". Desse modo, visando a produzir o material analisado, reunimos práticas e seus registros, enviados pelos alunos via WhatsApp e anotações em diário de campo. Podemos afirmar que nosso percurso metodológico inspira-se em e aproxima-se do que enunciam Balestrin e Soares (2012, p. 89) acerca da "etnografia de tela", isto é:

Um percurso etnográfico requer tempo, investimento, olhar mais e mais a tela, de diversos ângulos. Um caminho no qual o próprio ato de olhar transforma quem vê e o que vê. No decorrer da pesquisa, o sujeito pesquisador é também trabalhado, na medida em que é interpelado, transformado, desfeito, reconfigurado. Esse trabalho de análise permite que nossos olhares e nossas percepções se modifiquem, visto que somos também modificados nesse percurso, alterando muitas vezes o rumo da investigação e da própria vida.

Afirmamos que nos aproximamos dessa ideia de "etnografia de tela", pois nosso intuito foi proporcionar aos sujeitos escolares a quem propusemos as atividades a agudização do olhar que lê e atribui sentido às imagens, bem como, se torna capaz de produzir suas próprias narrativas visuais. Com isso buscamos, portanto, traçar uma escrita que elencasse e refletisse acerca de uma sequência didática centrada no desenvolvimento de letramentos, em especial, de letramento imagético, proposta para uma turma de anos iniciais da EJA. Vale destacarmos que o entendimento de sequência didática aqui adotado está alinhado ao que Pessoa (2014) enuncia: "sequência didática corresponde a um conjunto de atividades articuladas que são planejadas com a intenção de atingir determinado objetivo didático" [grifos da autora]. Dito de outra forma, a sequência didática relaciona-se ao modo como o trabalho pedagógico é organizado para atingir determinados objetivos. Dessa forma, o tempo estipulado é variável, levando em conta o que se quer ensinar, requer mediação e constante acompanhamento por parte do professor, através de momentos avaliativos que ocorrem durante e ao final do processo (PESSOA, 2014).

A turma a que se refere este trabalho era composta por cinco estudantes, com idades entre 41 e 71 anos. Desses, três eram homens e duas, mulheres. Três estudantes eram aposentados, mas continuavam a trabalhar fora para complementar a renda familiar, sendo que um atuava como porteiro/zelador de condomínio, um como pedreiro/pintor e uma aluna continuava a trabalhar como empregada doméstica. O quarto estudante era supervisor de jardinagem de uma empresa terceirizada que atua junto a universidade da qual o colégio faz parte e a quinta, cuidava de crianças em casa. Em 2020, todos os componentes do grupo encontravam-se em processo de alfabetização.

A instituição escolar onde atuamos, teve que fechar suas portas, assim como a maior parte das escolas brasileiras, ainda no mês de março de 2020, em razão da pandemia de Covid-19. Com o fechamento, a direção da instituição estabeleceu que buscaríamos manter o vínculo dos estudantes com a escola através do que foi denominado Estudos Dirigidos Remotos. Tal organização previa o envio semanal de atividades, postadas em formato PDF no site da escola. Aqueles estudantes que não podiam imprimir suas tarefas em casa, tinham a opção de solicitar impressões na escola. Acompanhando a teorização construída por Traversini e Lockmann (2021), podemos dizer que essa 
conformação pode ser chamada de escolarização delivery. Tal organização, que surge em meio a pandemia, separa o planejamento da sua execução. Assim, cabe aos professores o planejamento das aulas, que são disponibilizadas aos alunos a pronta entrega para execução em casa, com o auxílio das famílias.

Nesse processo, a escola solicitava que alunos e professores utilizassem o e-mail para se comunicar e para o envio das devoluções. No entanto, logo no início do período de fechamento das escolas, percebemos que essa metodologia não seria efetiva naquela turma. $\mathrm{O}$ acesso dos alunos a tecnologias digitais era muito restrito. Eles não possuíam computadores, e-mails ou mesmo, habilidade e autonomia para lidar com artefatos digitais. Destarte, a comunicação passou a se dar via um grupo de mensagens organizado no WhatsApp. Ainda assim, tal comunicação era muito precária e dependia de combinações com os familiares dos estudantes, tendo em vista que nem todos possuíam um smartphone. Dos cinco alunos, apenas dois possuíam celular próprio. Dois eram irmãos e a comunicação com os mesmos se dava através do celular da esposa de um deles e, com uma das alunas através do aparelho da filha. As mensagens trocadas no grupo geralmente eram enviadas em forma de áudio, devido às dificuldades de leitura.

No segundo semestre de 2020, passamos a organizar e entregar kits de atividades mensalmente. Esses kits eram compostos por, além dos planejamentos previstos para todo mês impressos, livros de leitura e outros materiais de apoio (jogos, revistas e jornais para recorte ou leitura, letras móveis, etc.) que pudessem auxiliar no processo de alfabetização dos/as estudantes vi. Procurávamos contemplar nas sequências didáticas construídas, todos os componentes curriculares que costumávamos trabalhar no cenário presencial, ainda que de forma adaptada. Assim, apesar do acesso restrito dos estudantes às tecnologias digitais, consideramos que podíamos dar continuidade ao processo de letramento digital promovido, em especial nas disciplinas de Polivalência e Cultura Digital. Como antes anunciado, dentre esses planejamentos que enviamos, escolhemos para examinar aqui, uma sequência didática que teve como mote principal, o desenvolvimento do letramento imagético.

\section{DESENVOLVIMENTO}

Em outubro de 2020, enviamos aos alunos atividades impressas que exploravam algumas histórias em quadrinhos escritas e ilustradas pelo artista Pablito Aguiarvii. A escolha da obra desse artista se deu por vários fatores. Pablito Aguiar é morador de Alvorada - cidade da região metropolitana de Porto Alegre-RS, onde residem alguns dos estudantes do CAp/UFRGS -, que, dentre suas obras, desenvolve uma série de histórias em quadrinhos denominada "Fala que eu desenho", a partir de entrevistas realizadas com pessoas da região, usando uma linguagem acessível e não infantilizada. $A$ escolha do gênero história em quadrinhos visava a facilitar a leitura e interpretação dos textos, pois esse tipo de gênero textual é formado por imagem e texto. Rojo (2006, p. 50) aponta que a proposição de práticas que relacionem "[...]escritos, falas e outras linguagens de forma dinâmica e mutuamente relacionada pode nos levar a preparar os alunos, [...] para as práticas de leitura, escrita e oralidade dos letramentos múltiplos e multimodais $[\ldots] "$.

Desse modo, ao longo de três semanas foram elaboradas e propostas atividades a partir de três histórias em quadrinhos de Pablito Aguiar. As histórias escolhidas tratavam de temas polêmicos, tais como a exploração da força de trabalho de ciclistas de aplicativos de entregas, a atuação de jornalistas na cobertura das dificuldades enfrentadas pela população menos favorecida economicamente no 
contexto pandêmico e, a solidão, especialmente de pessoas idosas em meio ao isolamento social imposto pelos cuidados necessários a proteção contra a Covid-19. Isso, de certo modo, aliado às questões de interpretação textual propostas nos planejamentos, objetivava a reflexão e o desenvolvimento de um olhar crítico frente aos desafios que muitos de nós vimos enfrentando na atualidade.

Nessa etapa do trabalho, priorizamos a identificação e significação do emprego de diferentes formatos de balões na construção das histórias em quadrinho, tentativas de exercer a leitura e interpretação crítica do material, bem como, o estabelecimento do entendimento de passagem temporal (início, meio e fim) da narrativa visual. Estruturamos esse objetivo final, pois em algumas aulas síncronas que realizamos no segundo semestre de 2020, em que priorizamos a leitura em voz alta (BOCASANTA e BERTACO, 2021), alguns alunos ainda não conseguiam estabelecer com precisão a passagem temporal ao ser solicitado o reconto oral do que haviam escutado. Entendemos, acompanhando Rojo (2006), portanto, que o suporte da imagem poderia ser importante na construção dessa compreensão.

Assim, nosso segundo movimento foi o envio de um conjunto de três imagens estáticas impressas que juntas apresentavam uma situação do cotidiano - preparar um chimarrão e tomar o mesmo durante um momento de trabalho/estudos - de uma das bolsistas atuantes no projeto de pesquisa que deu origem a esta escrita.

Figura 1 - Narrativa visual apresentada aos alunos.

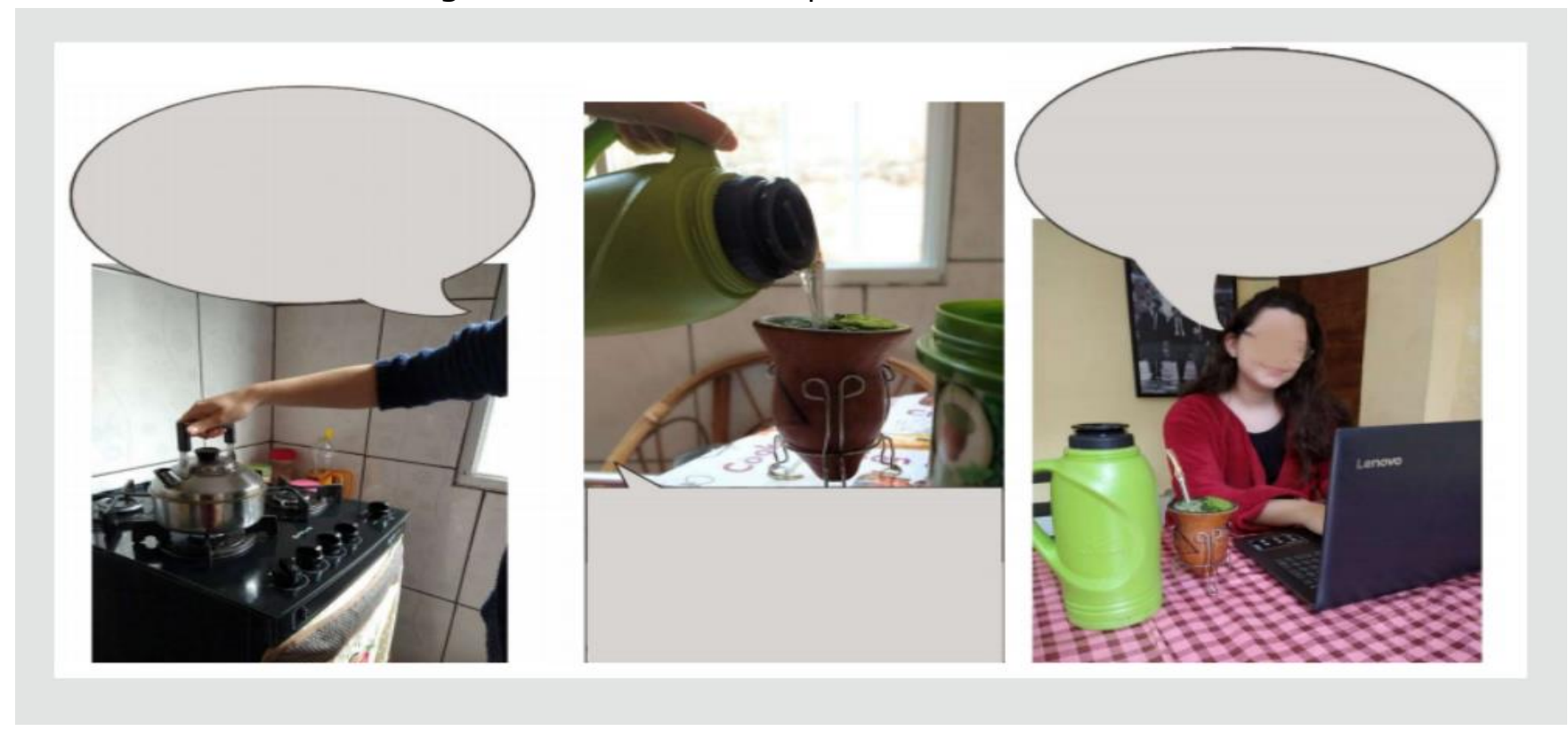

Fonte: acervo das autoras (2020).

Abaixo das imagens, foram disponibilizadas três caixas de textos com frases descritivas das ações presentes nas imagens. Os alunos deveriam, então, relacionar texto e imagem, inserindo essas frases nas caixas de diálogo correspondentes, como podemos observar na imagem reproduzida a partir do registro realizados por um dos alunos: 
Figura 2 - Registro de atividade realizada por um dos estudantes.

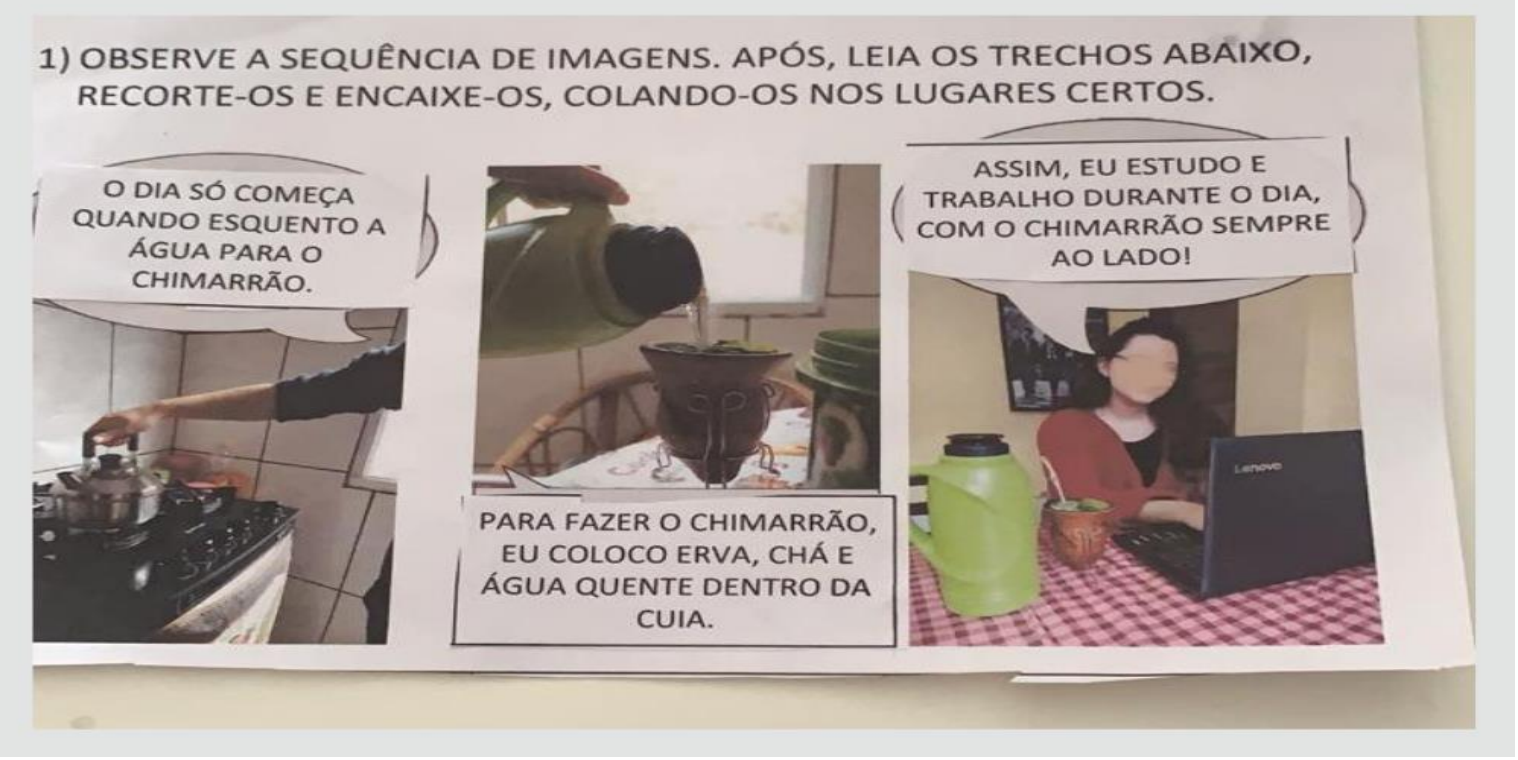

Fonte: acervo das autoras (2020).

Após, propusemos aos estudantes que registrassem, utilizando recursos digitais acessíveis, como celulares, imagens narrativas que contassem alguma ação do seu cotidiano em pelo menos três fotografias. Essas fotografias deviam, então, ser enviadas via WhatsApp para as professoras. De certo modo, esse tipo de atividade segue a recomendação de Zordan e Almeida (2020), quando sugerem que devemos perceber o caráter formativo das atividades cotidianas nesse período de fechamento das escolas, mesmo aquelas que se dão entre panos e louças para lavar. Nessa proposta, os alunos não necessitavam dedicar uma parte do seu dia exclusivamente para esse fim. Dos cinco alunos que faziam parte da turma naquele momento, quatro entregaram suas atividades, pois um estava doente e internado no hospital. Assim, uma aluna registrou o feitio de cuscuz; um aluno fotografou sua ida ao supermercado, escolhendo, pagando e guardando os produtos adquiridos no carro; outro aluno fotografou o preparo e o consumo de uma refeição e a última aluna enviou os passos compreendidos entre o preparo e o consumo de um café. O recebimento dessas imagens denotou avanços no entendimento dos alunos acerca de passagem temporal a partir de uma narrativa visual:

Figura 3 - Preparo de um cuscuz.
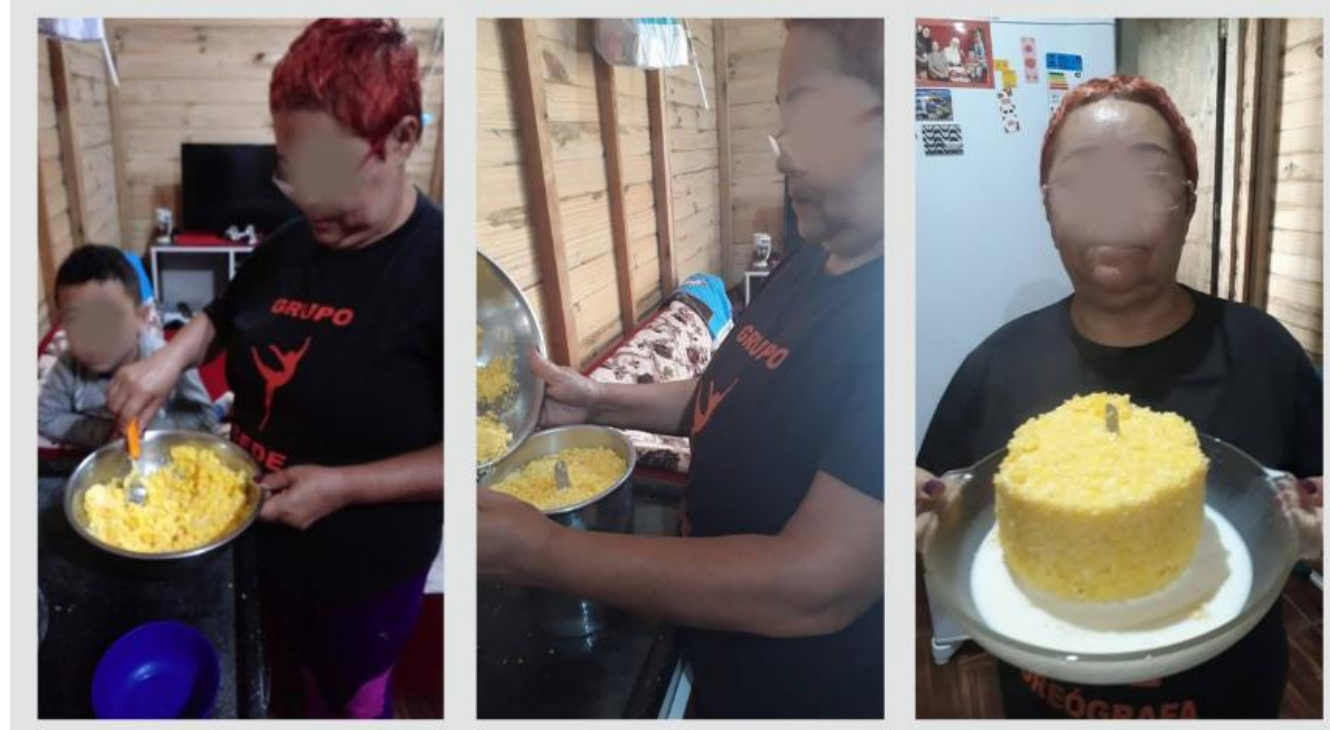

Fonte: acervo das autoras (2020). 
Figura 4 - Preparo e consumo de um café.

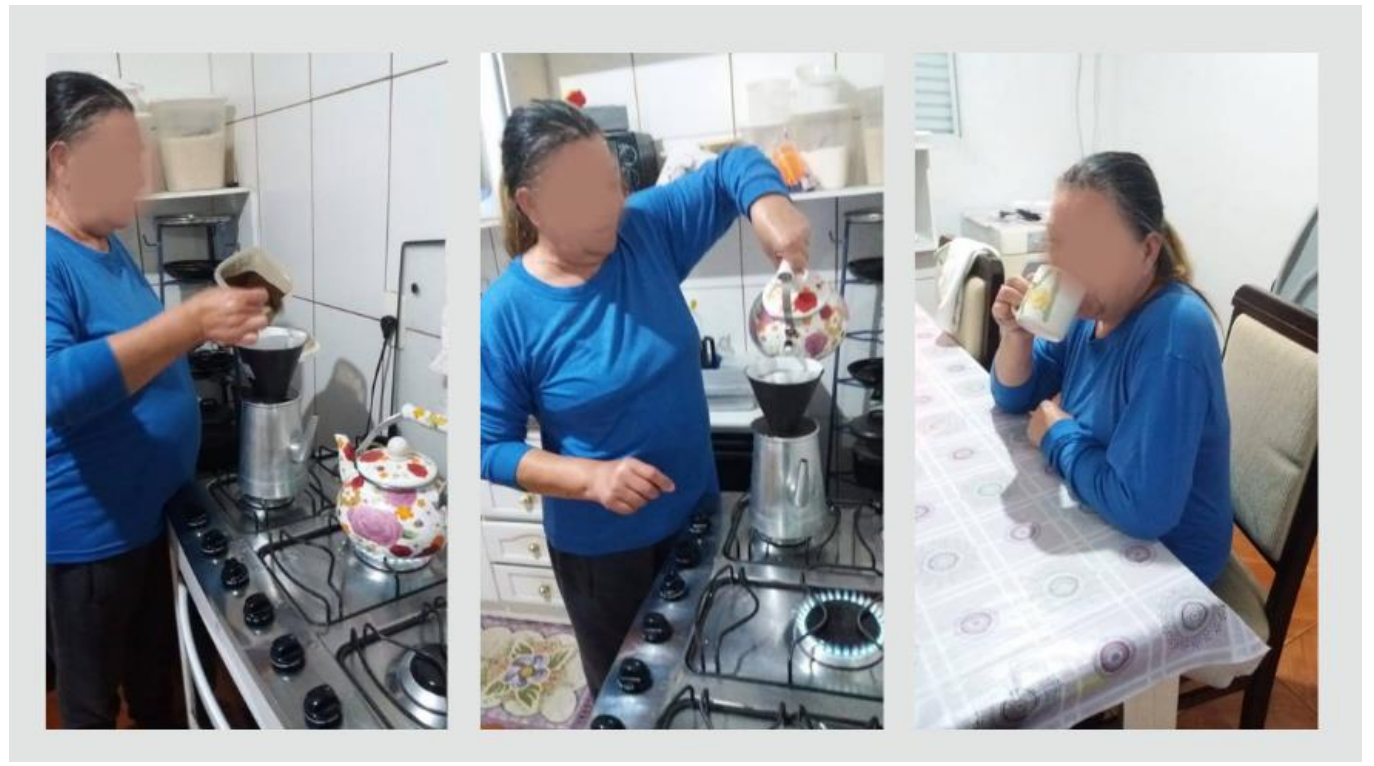

Fonte: acervo das autoras (2020).

Figura 5 - Ida ao supermercado.

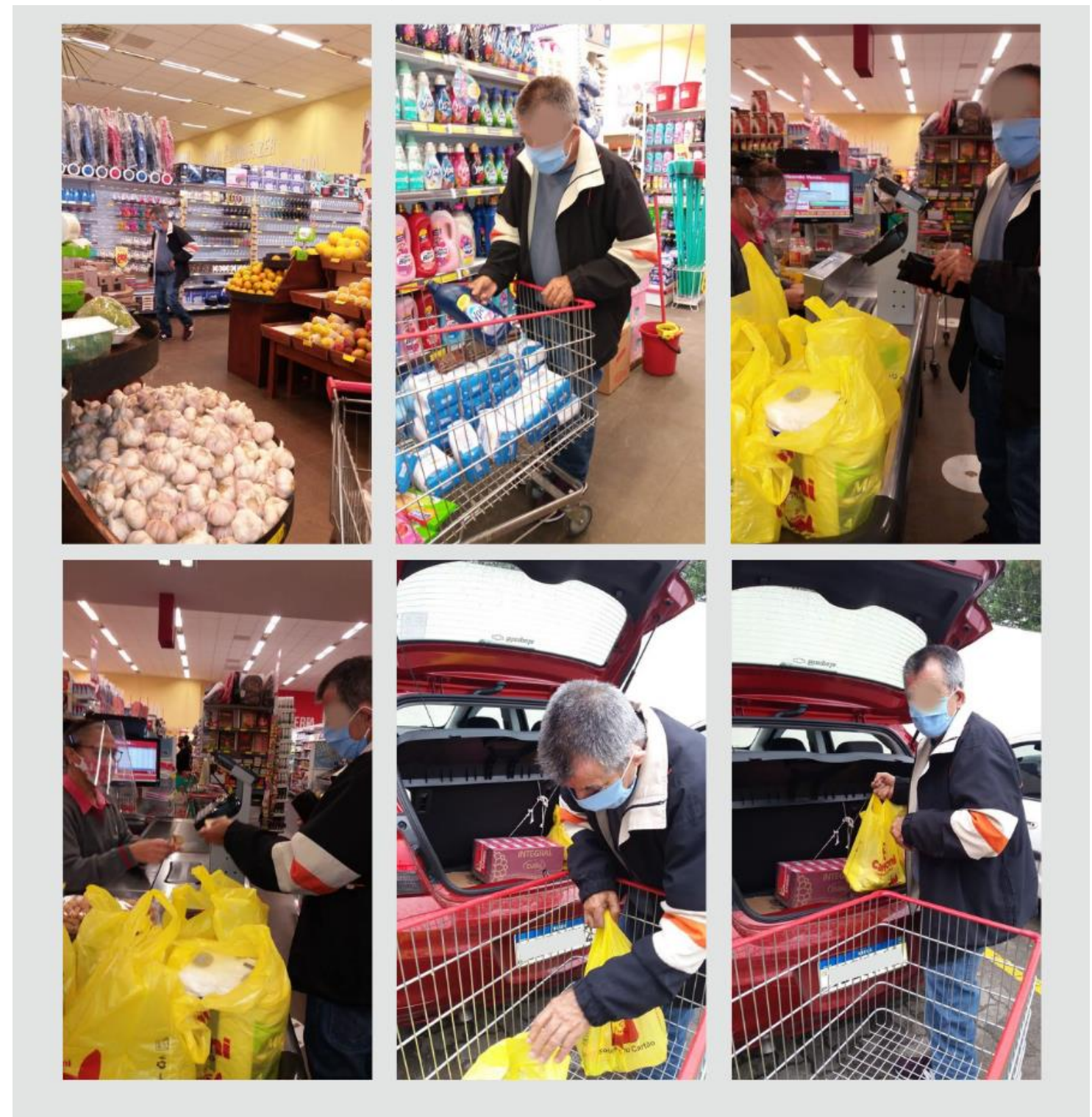

Fonte: acervo das autoras (2020). 
Figura 6 - Preparo e consumo de uma refeição.

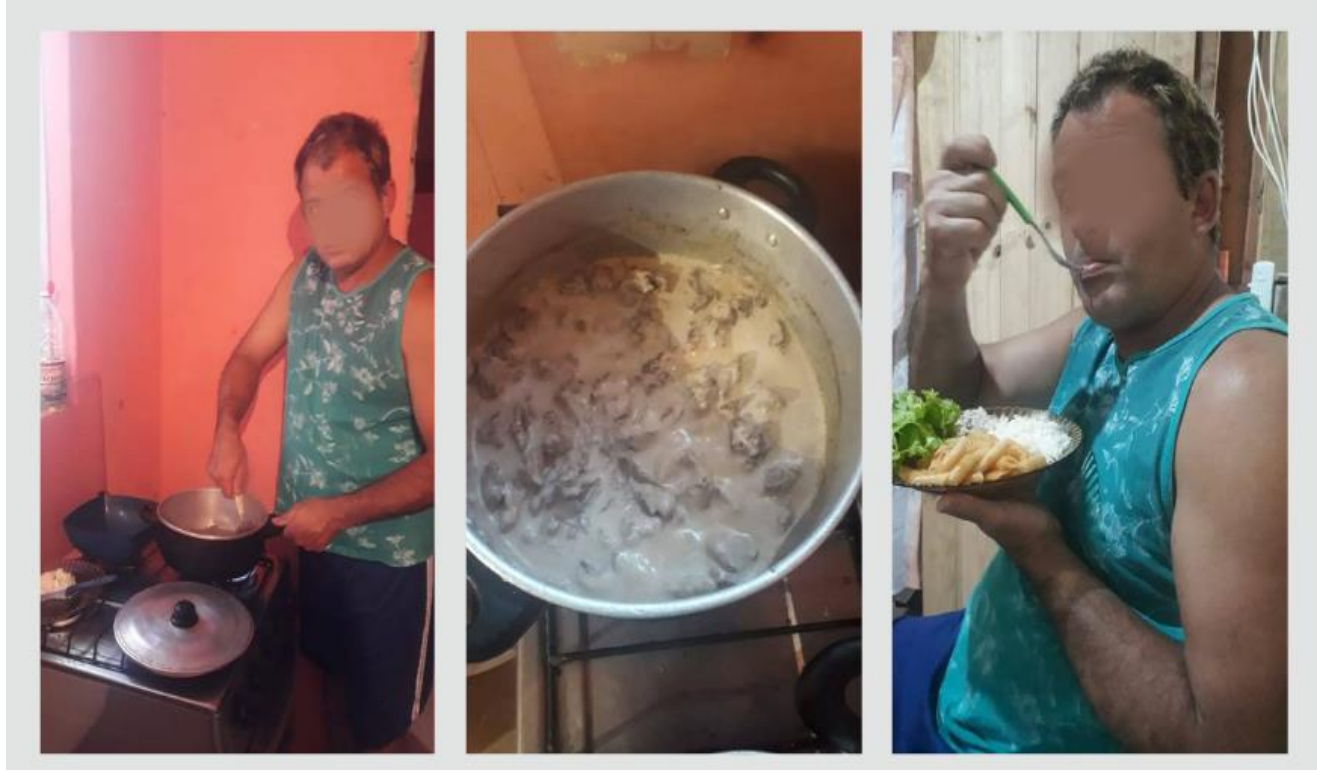

Fonte: acervo das autoras (2020).

Foi possível observar que a escolha das situações por parte dos estudantes não foi aleatória. Assim, M. ao nos enviar as fotos que narravam o preparo do cuscuz (Figura 3) enviou junto o seguinte áudio que aqui transcrevemos: "Tá aí, professora. Nessa primeira foto, estou preparando o cuscuz, né? A segunda estou botando na panela. A terceira, está pronto para comer. Será que tá bom esse trabalho, ou tenho que fazer outro?". Essa aluna, de origem nordestina, comentou, para a professora polivalente da turma, em uma das entregas de material, que havia feito um cuscuz naquele dia. A professora disse, então, que nunca havia comido cuscuz e que não sabia como fazer. A aluna respondeu, que na próxima entrega levaria um cuscuz para a professora - o que fez - e que a ensinaria como fazer aquele prato típico, que era sucesso entre seus familiares. Cabe destacar que essa estudante já faz uso de redes sociais. Em seu Instagram, que ela pediu para a professora polivalente seguir, várias imagens de alimentos que prepara são compartilhadas. É possível até mesmo assistir vídeos curtos em que descreve o preparo de alguns pratos e bebidas.

Já a estudante que produziu imagens em torno do preparo de um café (Figura 4) enviou, junto às fotos uma frase - provavelmente escrita pela filha no aplicativo de mensagens - em que fazia alusão ao bolo preparado pela esposa de um dos alunos, cuja foto tinha sido compartilhada no grupo dos alunos no WhatsApp na véspera: "Fazendo um cafezinho para acompanhar com o bolo do Seu M.!!!". Dois emoticons completavam a escrita, com uma carinha que remete ao apetite por algo e uma carinha com uma piscadinha. Podemos dizer que a aluna utilizou sua tarefa escolar para dar continuidade ao diálogo iniciado pelos colegas no grupo.

Podemos dizer, acompanhando Soares (2014), que apesar de não terem consolidado o processo de alfabetização, essas duas alunas que utilizam, respectivamente, redes sociais para divulgar o interesse pela culinária e aplicativos de mensagem para se comunicar, seja por áudio ou valendo-se de um intermediário como escriba, fazem uso de práticas sociais de escrita e leitura. Elas podem ser consideradas, portanto, indivíduos letrados.

O aluno cuja série de fotos descrevia sua ida ao supermercado (Figura 5) reclamava dias antes, no encontro com a professora para recebimento do kit de materiais, do custo da alimentação nos dias atuais e de que sempre entrava com dinheiro na carteira e saía com a mesma vazia do estabelecimento. Este, por sinal, foi o único que enviou mais de três imagens. 
Por último, o estudante que enviou o registro do preparo e consumo de um estrogonofe (Figura 6) sempre relatava nas aulas presenciais sobre seus dotes culinários, bem como, sempre era motivo de risadas quando contava acerca da expressiva quantidade de comida que consumia antes das aulas e que previa consumir ainda quando voltasse para casa. Os alunos sempre brincavam com ele, pois não achavam ser possível que ele comesse aquilo tudo que dizia comer.

Belmiro (2014) infere que cada cultura produz suas linguagens e com elas estrutura seu mundo de referências. Nessa direção, utilizamos as imagens ao nosso redor, armazenando-as na memória e com elas construindo significados. Com isso, podemos argumentar que "geramos imagens no nosso presente a partir de nossas vivências e selecionamos imagens de tempos passados e espaços passados, das quais nos apropriamos para nos expressar no nosso presente e para nos compreender como sujeitos sociais e históricos" (BELMIRO, 2014). Dito isso, podemos conjecturar que essa atividade possibilitou, de certo modo, que cada um escrevesse algo sobre si mesmo em forma de imagens. Mesmo sem dominar a leitura e a escrita alfabéticas, com o uso de recursos digitais acessíveis - no caso, aparelhos de celular - cada um deu a conhecer um pouco daquilo que é em sua vida privada: a mulher migrante nordestina que cultiva com sua família já formada no sul, a cultura alimentar em que foi criada, a mulher que faz um café para acompanhar o bolo no lanche da tarde, o homem que faz as compras da casa e que se preocupa com os rumos da economia e o valor exorbitante gasto no supermercado e o homem que gosta de cozinhar e sente-se orgulhoso de falar dessa habilidade que possui. Cada um, de seu modo, registrou algo que the era caro, e, claro, algo que lhe descrevia de uma maneira positiva frente aos demais. Naquelas imagens residiam diferentes formas de ver e de pensar sobre o mundo ao nosso redor.

Acompanhando Rosa (2015, p. 96), entendemos que a produção de narrativas visuais "ajuda-nos a situar nossos posicionamentos epistemológicos e ainda, a perceber os discursos que conformam nossas ações cotidianas". Nessa direção é possível conjecturar que através de ações cotidianas registradas em fotografias - como o preparo de um chimarrão ou o preparo de uma comida típica do nordeste -, é possível analisar influências culturais e sociais. Afinal, "de uma imagem catada, uma reprodução de obra artística ou um texto selecionado para compor um relato visual, podemos perceber nossas influências, lugares de fala e com isso, criar estratégias frente a uma tentativa de homogeneizar e padronizar narrativas [...]" (ROSA, 2015, p. 96). Dessa forma, através do exercício de pensar as imagens que nos rodeiam, é possível perceber e entender de onde surgem as referências visuais que nos acompanham.

Visto isso, com autorização dos estudantes, utilizamos as imagens enviadas para propor atividades. Não podemos deixar de destacar que usar tais imagens nas tarefas propostas também era um modo de promovermos a autoria desses sujeitos escolares. Em uma investigação que objetivou examinar a autoria e competências digitais de idosos no contexto da educação, Slodkowski et al. (2021) identificaram que existe uma lacuna em relação a trabalhos que tomem como objeto de estudo a competência autoria digital no que concerne a construção de materiais digitais por idosos. Isso nos direciona ao entendimento de que parece ser interditado aos idosos a produção autoral quando nos referimos às tecnologias. Em sua análise do discurso, Foucault (2006) destaca as relações de poder que conformam o que pode e o que não ser dito, afinal, "[...] o discurso não é simplesmente aquilo que traduz as lutas ou sistemas de dominação, mas aquilo por que, pelo que se luta, o poder do qual nos queremos apoderar" (FOUCAULT, 2006, p. 10). 
Dito de outro modo, nem sempre os modos de vida dos estudantes da EJA encontram espaço para se fazer presente no currículo ou mesmo, constituir-se em conhecimento escolar. Buscando fazer uma digressão nesse sentido, em um dos planejamentos semanais, enviamos as fotos da aluna preparando café, com frases correspondentes numeradas para fazer a associação:

Figura 7 - Atividade proposta $n^{0} 1$.

OBSERVE AS CENAS ABAIXO. LEIA AS FRASES E NUMERE AS CENAS DE ACORDO COM AS FRASES QUE DESCREVEM O QUE ACONTECE NAS MESMAS:
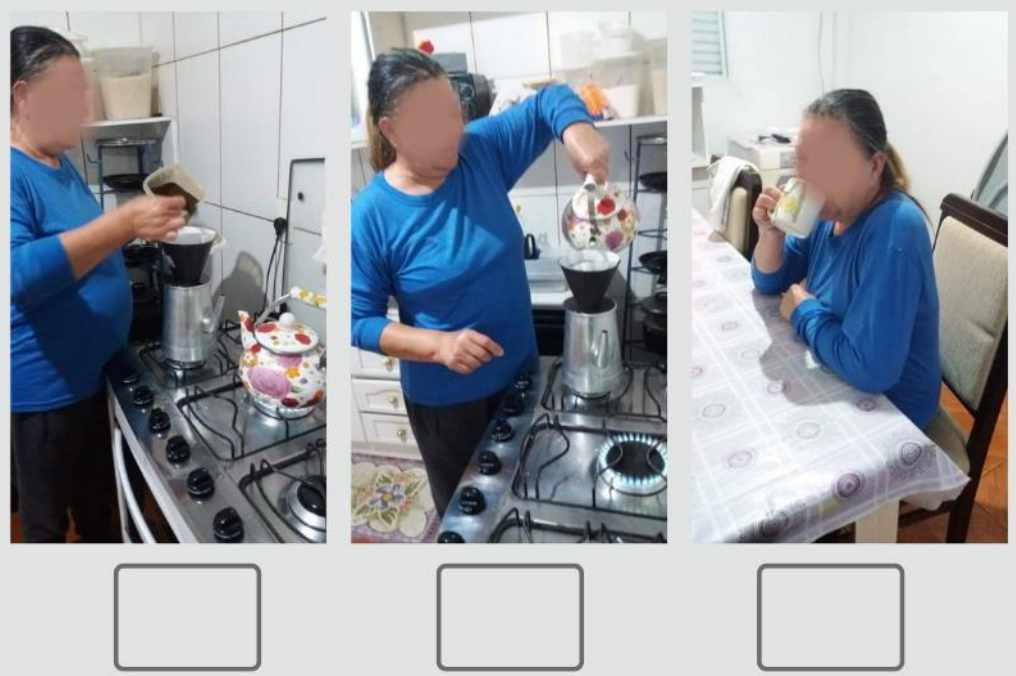

1 - ESTE CAFÉ FICOU UMA DELÍCIA!

2 - VOU FAZER UM CAFÉ PARA ACOMPANHAR O BOLO DE ESPINAFRE.

3 - DEPOIS DE AQUECER A ÁGUA E COLOCAR O PÓ NO FILTRO, VOU PASSAR MEU CAFÉ.

Fonte: acervo das autoras (2020).

Em outra atividade, solicitamos que os alunos criassem um diálogo que corresponderia ao que a aluna M. estava fazendo:

Figura 8 - Atividade proposta $\mathrm{n}^{0} 2$.

OBSERVE AS CENAS. ESCREVA DO SEU JEITO O QUE A M. ESTARIA FALANDO EM CADA CENA:
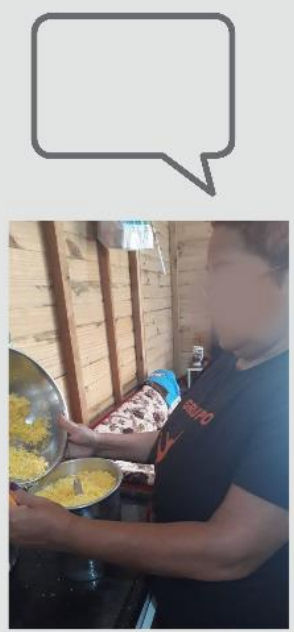
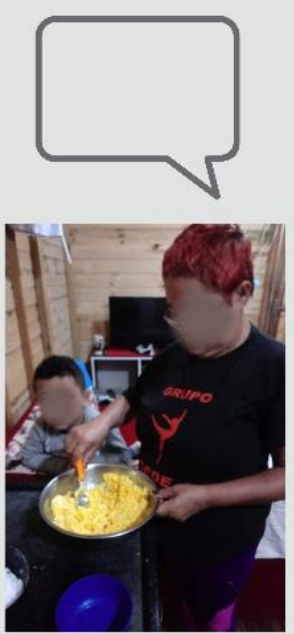
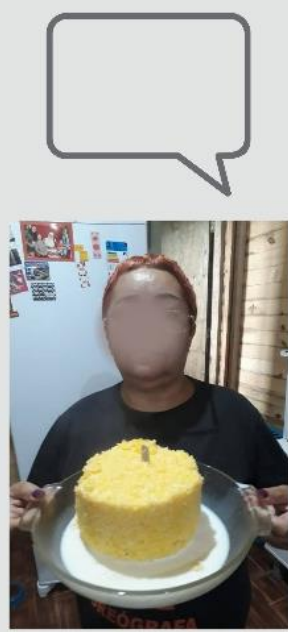

Fonte: acervo das autoras (2020). 
A atividade seguinte consistiu no recorte e ordenamento de frases descritivas das ações registradas por A. no supermercado.

Figura 9 - Atividade proposta nº 3.

OBSERVE AS IMAGENS ABAIXO. LEIA, RECORTE E ORDENE AS FRASES, COLANDO-AS ABAIXO DAS IMAGENS CORRESPONDENTES. ESCREVA UM TÍTULO PARA ESSA HISTÓRIA:
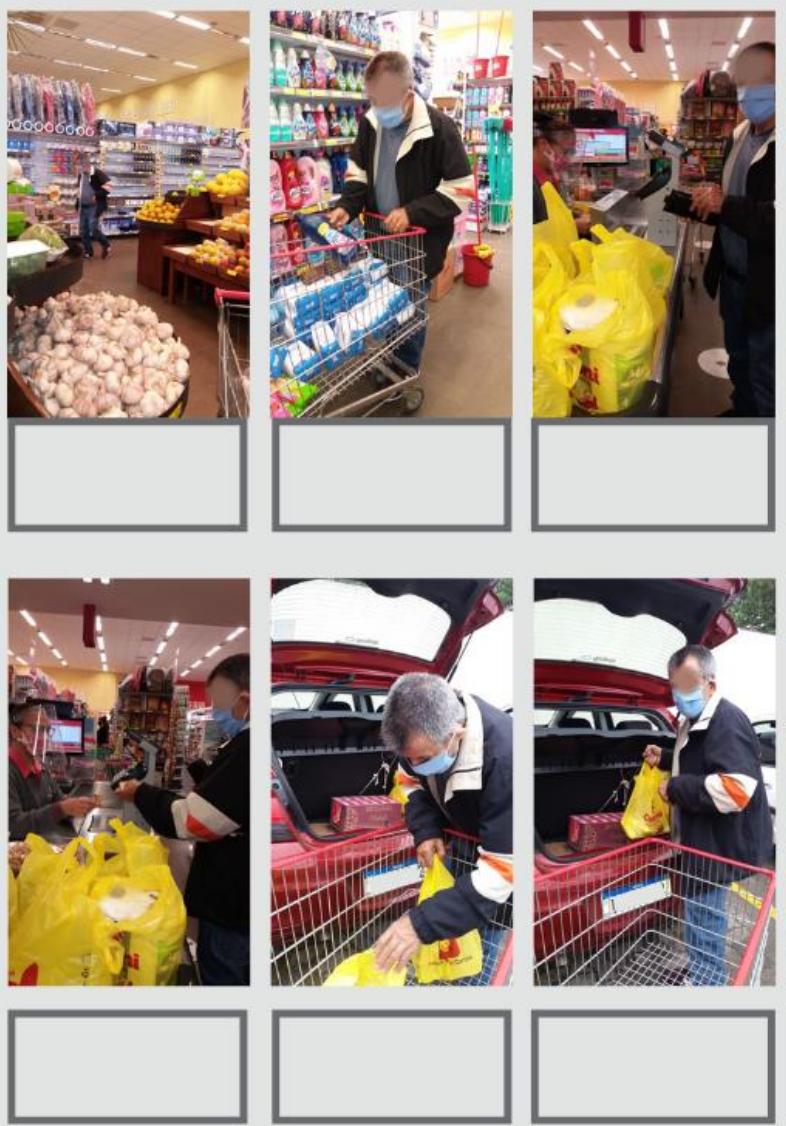

\begin{tabular}{|c|c|}
\hline $\begin{array}{l}\text { INFELIZMENTE, NA HORA DE PAGAR É } \\
\text { SEMPRE UM SUSTO, PORQUE A COMIDA } \\
\text { ESTÁ MUITO CARA. SEU A. SENTIU UMA } \\
\text { DOR NA HORA DE ABRIR A CARTEIRA. }\end{array}$ & $\begin{array}{l}\text { QUANDO PASSOU PELA PRATELEIRA DA } \\
\text { FARINHA, VIU QUE O PREÇO ESTAVA } \\
\text { OTIMO E RESOLVEU FAZER UM } \\
\text { ESTOQUE DO PRODUTO. }\end{array}$ \\
\hline $\begin{array}{l}\text { JÁ NO CARRO, GUARDOU TUDO NO } \\
\text { PORTA-MALAS E SEGUIU PARA CASA, } \\
\text { NÃO TÃO FELIZ. A FARINHA PARA FAZER } \\
\text { PÃO E BOLO ESTAVA GARANTIDA, MAS A } \\
\text { CARTEIRA VAZIA. }\end{array}$ & $\begin{array}{l}\text { DEPOIS DE RECLAMAR UM POUCO DOS } \\
\text { PREÇOS, ELE LEVOU AS SACOLAS PARA } \\
\text { O CARRO. }\end{array}$ \\
\hline $\begin{array}{l}\text { SEMANA PASSADA SEU A. FOI AO } \\
\text { SUPERMERCADO FAZER AS COMPRAS } \\
\text { MÊS. COMO SEMPRE, ELE CHEGOU } \\
\text { FELIZ E PASSOU PELAS PRATELEIRAS } \\
\text { PARA VER AS PROMOÇÕES. }\end{array}$ & $\begin{array}{l}\text { MAS, COMO NÃO TEM O QUE FAZER, } \\
\text { APENAS PAGOU SUAS COMPRAS. }\end{array}$ \\
\hline
\end{tabular}

Fonte: acervo das autoras (2020).

A última atividade proposta consistiu na solicitação de escritas espontâneas, em que os alunos deveriam escrever uma frase sobre cada imagem disponibilizada: 
Figura 10 - Atividade proposta no 4.

OBSERVE AS IMAGENS ABAIXO. ESCREVA, DO SEU JEITO, UMA FRASE SOBRE CADA UMA:

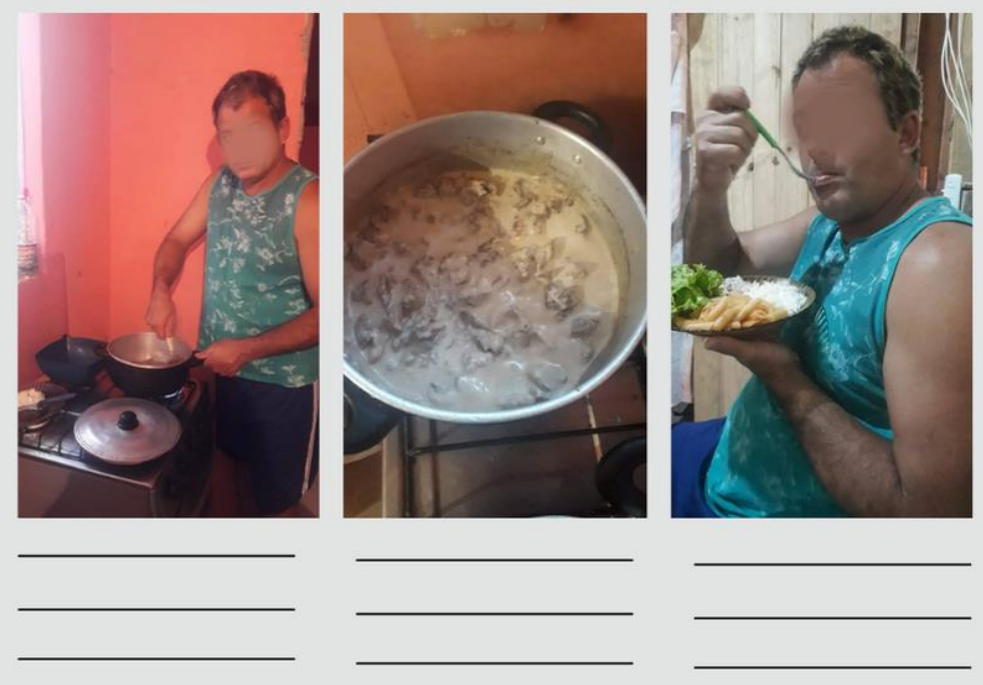

Fonte: acervo das autoras (2020).

Nossa sequência didática, portanto, passou pela apresentação e exploração do gênero textual história em quadrinhos, em que se buscava ler e interpretar determinados textos; a produção de narrativas visuais com recursos digitais acessíveis; para, então, compartilhar com todos o produto dos trabalhos individuais, visando a provocar releituras e mesmo, outras produções. Dito isso, podemos afirmar, acompanhando Kalantzis et al. (2020) e Ribeiro e Coscarelli (2014) que o trabalho aqui examinado esteve comprometido com uma pedagogia voltada para os multiletramentos.

Seguindo Belmiro (2014), podemos afirmar que "estabelecer caminhos que deem condições de explorar possibilidades de leitura de imagens e de interação através delas amplia o alcance das reflexões acerca de seus processos e usos". Essa autora, que não utiliza o termo letramento imagético, mas sim letramento visual, ainda infere que promover esse tipo de letramento não se limitaria a oferecer condições para o desenvolvimento da competência de leitura de imagens. Tal processo auxiliaria a lidar com múltiplas linguagens visuais, fortalecendo, assim, o entendimento dos usos de diferentes mídias.

Como movimento final, resolvemos apresentar aos alunos outra forma de utilizar as imagens produzidas por eles. Nossa ideia inicial era ensiná-los a criar gifs. Gifé a sigla de Graphics Interchange Format que poderíamos traduzir, de forma livre, para formato de intercâmbio de gráficos. No entanto, discutimos em reunião de planejamento que mesmo criando tutoriais escritos ou por vídeos para envio no grupo de WhatsApp os alunos teriam muitas dificuldades para realizar tal tarefa. Entendemos que as limitações de acesso a dispositivos digitais adequados e mesmo, as dificuldades para lidar com artefatos digitais, apresentadas pelos sujeitos escolares e seus familiares seriam limitadores da tarefa.

Ainda assim, concluímos, a partir de alguns estudos que exploramos, como os de Sene et al. (2017), Miolla (2017) e Melo (2020), que o gif teria potencial para se constituir em um importante recurso didático e resolvemos explorá-lo de alguma forma. Nos apoiamos também na BNCC (2017), que diz que "compreender uma palestra é importante, assim como ser capaz de atribuir diferentes sentidos 
a um gif ou meme. Da mesma forma que fazer uma comunicação oral adequada e saber produzir gifs e memes significativos também podem sê-lo" (BRASIL, 2017, p. 69).

Nesse sentido, utilizando as imagens enviadas pelos estudantes, produzimos gifs e compartilhamos no grupo de WhatsApp da turma. Após, a bolsista que atuava junto a turma fez um vídeo explicando como surgiu, em que consistia e possibilidades práticas de uso do gênero textual gif. Alguns alunos reagiram com emoticons e/ou áudios no WhatsApp, mas sentimos que o contexto dos estudos dirigidos à distância, a avaliação da atividade ficou um pouco restrita, bem como, dificultou um aprofundamento do processo de apropriação de práticas de letramento digital e especificamente de letramento imagético, já que não foi possível ensinar os estudantes a produzir seus próprios gifs. Ademais, cabe ressaltar, que ainda que todos tenham feito parte das cenas retratadas, não foram eles os responsáveis pelo manejo dos celulares utilizados na produção das fotografias. Eles podem ter escolhido situações, ângulos e fotos a serem enviadas, mas não manipularam os aparelhos. Isso, de certo modo, aponta para outra limitação da proposta, que pretendemos repetir quando for possível restabelecer o convívio presencial na escola.

\section{CONSIDERAÇÕES FINAIS}

Ao final dessa escrita, observamos potencialidades e limitações da realização de atividades de letramento imagético na EJA no contexto remoto. Tais atividades possibilitaram o desenvolvimento da noção de passagem de tempo de narrativas, a leitura de imagens, bem como a autoria dos estudantes, na produção de imagens. Ao mesmo tempo, como limitações, nossa reflexão indicou que o contexto remoto impossibilitou que os estudantes pudessem produzir seus próprios gifs.

Entretanto, ao longo do processo, percebemos que mais do que a apropriação de técnicas ou conceitos por parte dos estudantes, temos que levar em conta os efeitos da discussão das práticas pedagógicas que realizamos. Apoiadas em estudos sobre letramento, numeramento e EJA, Fonseca e Simões (2015) inferem que conceitos centrados apenas no conjunto de habilidades que devem ser apropriadas para atender a demandas de diferentes situações sociais, que nos induzem a vincular essas habilidades às consequências positivas dessa apropriação, seria um reducionismo quando falamos do entrecruzamento letramento e EJA. "Com efeito, estudos sobre os usos sociais da leitura, da escrita e de matemática por jovens e adultos pouco escolarizados nos permitem conhecer os alunos e as alunas da EJA como sujeitos de (outras) culturas e de (outros) conhecimentos", o que nos possibilitaria qualificar investigações focadas nos impactos da escolarização "em relação às práticas de letramento e numeramento desses sujeitos" (FONSECA e SIMÕES, 2015, p. 521). Isso nos mobilizou, portanto, a olharmos para além das habilidades apropriadas pelos estudantes ao longo das propostas, como a construção e envio de narrativas visuais baseadas no cotidiano. Estávamos interessadas, sobretudo, naquilo que nossos alunos e alunas narravam sobre si e na qualificação de nossas práticas docentes ao incorporarmos tais vivências em nossos planejamentos.

Do mesmo modo, acompanhamos Zacharias (2016), ao argumentar que, utilizar os recursos digitais como objeto de ensino, exige-nos mais do que trabalhar com os alunos os gêneros que circulam nessas mídias - como os gifs - ou ainda, as técnicas para manejar tais artefatos. Para a autora, "a leitura no ambiente digital inclui controlar os propósitos de leitura, buscar, selecionar, interpretar e contrastar informações" (ZACHARIAS, 2016, p. 28). Dito isso, queremos destacar que nosso trabalho também esteve interessado em ajudar nossos alunos não apenas a dominar técnicas, mas antes, a compreender como significavam os usos que faziam de artefatos digitais no cotidiano. 
Não podemos deixar de destacar que o contexto pandêmico e o consequente fechamento das escolas têm sido especialmente complexo para o público que frequenta a EJA. A manutenção do vínculo entre esses estudantes e a instituição escolar têm sido um desafio. Cabe, no entanto, ressaltar, que nosso intento, aqui, não foi fornecer uma receita pronta para ser aplicada em qualquer turma de anos iniciais da EJA, mas apenas, fazer um exercício de reflexão acerca de práticas pedagógicas centradas, em especial, no desenvolvimento do letramento imagético.

\section{REFERÊNCIAS}

BOCASANTA, Daiane Martins; BERTACO, Isabelle. Encontros virtuais de leitura na EJA: limites e possibilidades de práticas pedagógicas em tempos pandêmicos. Olhares \& Trilhas. Uberlândia, $v$. 23, n. 2, abri.-jun. 2021, p. 263-283. Disponível em:

http://www.seer.ufu.br/index.php/olharesetrilhas/article/view/59086/31982 Acesso em 01/07/2021.

BOCASANTA, Daiane Martins; RAPKIEWICZ, Clevi Elena. Letramento digital na Educação de Jovens e Adultos: uma experiência no Colégio de Aplicação da UFRGS. Cadernos do Aplicação. Porto Alegre, v. 32, n. 2, ago.-dez. 2019, p. 57-65. Disponível em: https://seer.ufrgs.br/CadernosdoAplicacao/article/view/101050/58493 Acesso em 24/06/2021.

BOCASANTA, Daiane Martins; WANDERER, Fernanda; KNIJNIK, Gelsa. Educação de jovens e adultos e os conhecimentos tecnocientíficos: analisando as relações entre ciência, tecnologia e matemática. Horizontes. v. 34, n. 3, 2016, p. 81-92. Disponível em: https://revistahorizontes.usf.edu.br/horizontes/article/view/349 Acesso em 04/07/2021.

BOCASANTA, Daiane Martins; WANDERER, Fernanda; KNIJNIK, Gelsa. Dispositivo de tecnocientificidade e Educação de Jovens e Adultos (EJA). Educação. Santa Maria, v. 44, 2019, p. 1-20. Disponível em: https://periodicos.ufsm.br/reveducacao/article/view/30910/pdf. Acesso em: 20/06/2021.

BALESTRIN, Patrícia Abel; SOARES, Rosângela. "Etnografia de tela": uma aposta metodológica. Dagmar Estermann; PARAÍSO, Marlucy Alves (orgs.) Metodologias de pesquisas pós-críticas em educação. Belo horizonte: Mazza Edições, 2012, p. 63-86.

BRASIL, Base Nacional Comum Curricular. 2018. Disponível em: http://basenacionalcomum.mec.gov.br/images/BNCC_EI_EF_110518_versaofinal_site.pdf Acesso em 11 Jul. 2021.

BRASIL. Resolução 01 de 2021. Diretrizes operacionais para a Educação de Jovens e Adultos nos aspectos relativos ao seu alinhamento à Política Nacional de Alfabetização (PNA) e à Base Nacional Comum Curricular (BNCC) e Educação de Jovens e Adultos a Distância. Disponível em: https://www.in.gov.br/en/web/dou/-/resolucao-n-1-de-28-de-maio-de2021-323283442. Acesso em 11 de Jul. de 2021.

BELMIRO, Celia Abicalil. Letramento visual. In: Glossário Ceale: termos de alfabetização, leitura e escrita para educadores / Isabel Cristina Alves da Silva Frade, Maria da Graça Costa Val, Maria das Graças de Castro Bregunci (orgs). Belo Horizonte: UFMG/Faculdade de Educação, 2014. Disponível em: http://www.ceale.fae.ufmg.br/app/webroot/glossarioceale/verbetes/letramento-visual Acesso em 04 Jul. 2021.

DEODORO, Tainá Maria Silva; BERNARDO, Lilian Dias; SILVA, Allana Karoline Chaves da; RAYMUNDO, Taiuani Maquine; SCHEIDT, Isabela Vinharski. A inclusão digital de pessoas idosas em momento de pandemia: relato de experiência de um projeto de extensão. Revista Extensão em 
Foco. Palotina, n. 23 (Especial), p. 272-286, jun. 2021. Disponível em:

https://revistas.ufpr.br/extensao/article/view/80577/pdf Acesso em 07 Jul. 2021.

DONDIS, Donis A. Sintaxe da linguagem visual. 3. ed. São Paulo: Martins Fontes, 2007.

DUSSÉL, Inés. La escuela em la pandemia. Reflexiones sobre lo escolar en tiempos dislocados.

Práxis Educativa, Ponta Grossa, v. 15, p. 1-16, 2020. Disponível em:

https://www.revistas2.uepg.br/index.php/praxiseducativa Acesso em 28 jun. 2021.

FAVERO, Rute Maria; CARDOSO, Raíssa Gabriella Wasem. A utilização das redes sociais na modalidade EJA. Cadernos do Aplicação, Porto Alegre, v. 33, n. 2, Jul.-Dez. 2020. Disponível em: https://www.seer.ufrgs.br/CadernosdoAplicacao/article/view/104604/60970 Acesso em 05 Jul. 2021.

FONSECA, Maria da Conceição Ferreira Reis; SIMÕES, Fernanda Maurício. Apropriação de práticas de numeramento na EJA: valores e discursos em disputa. Educ. Pesqui., São Paulo, v. 40, n. 2, p. 517-531, junho de 2014. Disponível em:

<http://www.scielo.br/scielo.php?script=sci_arttext\&pid=S1517-

97022014000200014\&lng=en\&nrm=iso>. Acesso em 10 Jul. 2021.

FOUCAULT, Michel. A Ordem do Discurso. São Paulo: Edições Loyola, 14 ed. 2006.

KALANTZIS, Mary; COPE, Bill; PINHEIRO, Petrilson. Letramentos. Campinas: Editora UNICAMP, 2020, 408 p.

LAZZARATO, Maurizio. Signos, máquinas, subjetividades = Signes, machines, subjectivités. São Paulo: Edições Sesc São Paulo, 2014.

MELO, Ediclécia Sousa de. 0 uso do GIF como recurso didático no ensino de língua

portuguesa para surdos. Artigo (Especialização em Ensino de Língua Portuguesa como 2a Língua para Surdos). Instituto Federal da Paraíba - IFPB/Pró-Reitoria de Pesquisa, Inovação e PósGraduação. Diretoria de Educação a Distância, 2020.

MEYER, Dagmar Estermann; PARAÍSO, Marlucy Alves. Apresentação. In: MEYER, Dagmar Estermann; PARAÍSO, Marlucy Alves (orgs.) Metodologias de pesquisas pós-críticas em educação. Belo horizonte: Mazza Edições, 2012, p. 15-22.

MIOLLA, Gabriélli Tainá. Animações em gif como ferramenta didática para o ensino de zoologia. Trabalho de Conclusão de Curso (graduação). Universidade Tecnológica Federal do Paraná. Curso de Ciências Biológicas. Dois Vizinhos, 2017.

PESSOA, Ana Cláudia Gonçalves. Sequência didática. In: Glossário Ceale: termos de alfabetização, leitura e escrita para educadores / Isabel Cristina Alves da Silva Frade, Maria da Graça Costa Val, Maria das Graças de Castro Bregunci (orgs). Belo Horizonte: UFMG/Faculdade de Educação, 2014. Disponível em:

http://www.ceale.fae.ufmg.br/app/webroot/glossarioceale/verbetes/sequencia-didatica Acesso em 04 Jul. 2021.

RIBEIRO, Ana Elisa; COSCARELLI, Carla Viana. Letramento digital. In: Glossário Ceale: termos de alfabetização, leitura e escrita para educadores / Isabel Cristina Alves da Silva Frade, Maria da Graça Costa Val, Maria das Graças de Castro Bregunci (orgs). Belo Horizonte: UFMG/Faculdade de Educação, 2014. Disponível em: 
http://www.ceale.fae.ufmg.br/app/webroot/glossarioceale/verbetes/letramento-digital Acesso em 04 Jul. 2021.

RODRIGUES, Walace. Letramento imagético e midiático em arte-educação. Conhecimento \& Diversidade, [S.I.], v. 6, n. 12, p. 90-101, dez. 2014. ISSN 2237-8049. Disponível em: <https://revistas.unilasalle.edu.br/index.php/conhecimento_diversidade/article/view/1607>. Acesso em: 4 jul. 2021. doi:http://dx.doi.org/10.18316/1607.

ROJO, Roxane. As relações entre fala e escrita: mitos e perspectivas - caderno do professor. Belo Horizonte: Ceale, 2006.

ROSA, Aline Nunes da. Sobre mudar de paisagens, sobre mirar com outros olhos - narrativas a partir de deslocamentos territoriais. 2015. $284 \mathrm{f}$. Tese (Doutorado em Arte e Cultura Visual) Universidade Federal de Goiás, Goiânia, 2015.

SENE, Hélen Maria Mendes de; ANDRADE, André Luiz Silva; SILVA, André Maciel da; VERA, José Casto Nogales; JUNIOR, Antonio Fernandes Nascimento. O ensino dos conceitos de solstício e equinócio e das estações do ano a partir do uso de gif como recurso didático. Periódico

Eletrônico Fórum Ambiental da Alta Paulista. Volume 13, n. 07, 2017, p. 1-15.

SILVA, Renata Borges Leal da; COUTO JUNIOR, Dilton Ribeiro. INCLUSÃO DIGITAL NA EDUCAÇÃO DE JOVENS E ADULTOS (EJA): PENSANDO A FORMAÇÃO DE PESSOAS DA TERCEIRA IDADE.

Revista Docência e Cibercultura, [S.I.], v. 4, n. 1, p. 24-40, abr. 2020. ISSN 2594-9004. Disponível em: <https://www.e-publicacoes.uerj.br/index.php/re-doc/article/view/46818/33253>. Acesso em: 07 jul. 2021. doi:https://doi.org/10.12957/redoc.2020.46818.

SLODKOWSKI, Bruna Kin; AKAZAKI, Jacqueline Mayumi; MACHADO, Letícia Rocha; BEHAR, Patrícia Alejandra. Competência autoria digital de idosos: uma revisão sistemática da literatura acerca dos conceitos. Revista Educar Mais, [S. l.], v. 5, n. 4, p. 805-820, 2021. DOI:

10.15536/reducarmais.5.2021.2452. Disponível em:

http://periodicos.ifsul.edu.br/index.php/educarmais/article/view/2452. Acesso em: 13 jul. 2021.

SOARES, Magda. Novas práticas de leitura e escrita: letramento digital. Educação e Sociedade, Campinas, v. 23, n. 81, p. 143-160, dez. 2002. Disponível em: http://www.scielo.br/pdf/es/v23n81/13935.pdf Acesso em 07 Jul. 2021.

SOARES, Magda. Letramento: um tema em três gêneros. Belo Horizonte: Autêntica Editora, 3. ed., 2014.

TERRA, Márcia Regina. Letramento \& letramentos: uma perspectiva sócio-cultural dos usos da escrita. DELTA: Documentação de Estudos em Linguística Teórica e Aplicada [online]. 2013, v. 29, n. 1. Disponível em: https://doi.org/10.1590/S0102-44502013000100002 . Acesso 27 Jun. 2021, p. 29-58.

TRAVERSINI, Clarice Salete; LOCKMANN, Kamila. Escolarização delivery. Textura. FISS, D. M. L.; UBERTI, L. (orgs.). Quarentenário Pequeno Breviário dos Tempos de Pandemia. v. 23, n. 53. p. 447-514. DOI: https://doi.org/10.29327/227811.23.53-21 Disponível em:

http://www.periodicos.ulbra.br/index.php/txra/article/view/6348 Acesso em: 10 Jul. 2021.

ZACHARIAS, Valéria Ribeiro de Castro. Letramento digital: desafios e possibilidades para o ensino. In: COSCARELLI, Carla Viana (org.). Tecnologias para aprender. 1. ed. São Paulo: Parábola Editorial, 2016, p. 15-26. 
ZORDAN, Paola; ALMEIDA, Verônica Domingues. Parar pandêmico: educação e vida. Práxis Educativa, Ponta Grossa, v. 15, p. 1-18, 20 jul. 2020. DOI:

https://doi.org/10.5212/PraxEduc.v.15.15481.077 Disponível em:

https://revistas2.uepg.br/index.php/praxiseducativa/article/view/15481/209209213435. Acesso em: 05 Jul. 2021.

Submissão: 17/07/2021

Aceito: 08/09/2021

\footnotetext{
' $O$ termo se refere às notícias falsas veiculadas na internet. Surgido no contexto das eleições presidenciais dos EUA em 2016, foi incorporado ao nosso vocabulário brasileiro durante as eleições de 2018.

ii Conforme explicitamos mais adiante.

iii Não concordamos com a centralidade dada a apenas esses dois componentes no currículo escolar voltado para os anos iniciais da EJA, porém, visando manter o foco deste trabalho, vamos nos abster dessa discussão nesse espaço de escrita.

iv Este trabalho foi produzido no âmbito da pesquisa "Tecnocientificidade, Matemática e Educação de Jovens e Adultos", desenvolvido no Colégio de Aplicação da UFRGS, sob a coordenação da professora Daiane Martins Bocasanta e contou com a atuação de uma das duas bolsistas de Iniciação Científica vinculadas ao projeto no período.
}

${ }^{\vee}$ A professora polivalente da turma é a professora pedagoga.

vi Já ao final daquele semestre, de forma muito incipiente, realizamos quatro atividades síncronas por videochamada de WhatsApp para encontros de leitura em voz alta e atividades de alfabetização (BOCASANTA e BERTACO, 2021), utilizando, para isso, um recurso a que todos tinham acesso, ainda que através de intermediários: os celulares.

vii Disponível em: https://www.pablitoaguiar.com.br/inicio/entrevistas-em-quadrinhos/fala-que-eu-desenho/ Acesso em 04 Jul. 2021. 